\title{
The Role of Supply Chain Management in the System of Kintamani Coffee Production in District Bangli, Bali
}

\author{
I.M. Kartika *, I.M.A. Suwandana, L.P.V Indah \\ Ngurah Rai University \\ Denpasar, Bali, Indonesia \\ *kartikamade64@gmail.com
}

\begin{abstract}
The aims of this research to determine the best supply chain model of Kintamani Coffee were analyzed qualitatively. The sources of data taken from; observation field documentation and interview with farmers, relevant agencies from the Office of Plantation and Agriculture, Trade Office, as well as private agencies as partners. The results of field observations and documentations that efforts to supply Kintamani coffee commodity supply chain can be better done by exploring the potential and opportunity to position itself more strategically and more dynamically in the global value chain through increasing product value (quality differentiation) processing of raw seeds downstream and increasing the value through a more efficient process (productivity at better farm level). In addition, it also provided training on post-harvest processing coffee beans to farmers by a private partner in order to sell coffee at the level of farmers can better compete, produce reached 2500 tons and it is expected to enhance the brand of coffee in Kintamani to local, national and international level.
\end{abstract}

Keywords-Supply Chain Management; Value Chain; Product Value

\section{INTRODUCTION}

Indonesia has become the world's major coffee producers and Indonesia in recent years to compete with Colombia to become the world's third-largest producer after Brazil and Vietnam. Indonesia ranks fourth in terms of volume of export to third countries under the previously mentioned with the percentages share of exports amounted to 5.92 .

Indonesia has become the world's major coffee producers and in the last few years, however, having regard to the condition may not necessarily be making coffee export volume from Indonesia is also great. Indonesia's coffee export volume recorded decline and was ranked seventh largest in the world [1]. This is confirmed by the data mentioned that since 1990 until 2016 production has not increased significantly and undergone ups and downs between 421,833 up to 267,058 tonnes per year. Even the export of coffee which was recorded in the year 2016 valued at 267,058 tonnes compared to the previous year significantly down in the year 2015 amounting to 502,021 tons [2]. This happens because the coffee sector in Indonesia is generally considered to have performance that is far from its potential. Yields are still not increasing significantly, and overall production is more or less there is still no improvement since the year 1990.

The world price for coffee is relatively high since the year 2007 has not been a comparable result in increased investment for farmers and coffee production in Indonesia. Even so, many households in rural areas in Indonesia who are engaged in the business of coffee people show that increased productivity coffee contribute to poverty reduction and resilience of livelihoods in Indonesia [3].

\section{LITERATURE REVIEW}

Exports of processed coffee product dominated product instant coffee, extracts, essences and concentrates of coffee spread to the export destination countries such as the Philippines, Malaysia, Thailand, Singapore, China and the United Arab Emirates [4]. This coffee has a distinctive flavour, pest-resistant disease, dense and fruitful high productivity [5]. The Arabica coffee grown by farmers in Kintamani is an important source of income for farmers and it has been successfully marketed to the special segment, as are the majority of farmers have been implementing the practice of cultivating the good, but the way the processing postharvest mostly dry less well the quality [6]. This condition certainly will not be able to increase the prosperity of coffee farmers who have been trying to produce a superior coffee. The level of knowledge of the procedures for processing the coffee chain's length as well as post-harvest distribution of coffee to make the price received at the level of farmers tend to be low [7]. Notice to the condition necessary improvements on various aspects in the production of superior coffee Kintamani especially that carries on the distribution chain Coffee Kintamani for all parties concerned especially the coffee farmers could get results, it deserves for what is done during this time. 
attribute is used in reference to partnership research include

\section{Supply chain management}

The concept of supply chain management is a new concept which sees the entire activity of the company is an integrated part. In this case the integration of companies in the upstream (upstream) in providing raw materials and integration on the lower reaches (downstream) in the process of distribution and marketing of the product.

SCM is a series of approaches applied to integrate suppliers, employers, another storage warehouses and efficiently to products produced and distributed with the right quality, the right location and time to minimize costs and satisfy customer needs [8]. SCM is a series of approaches applied to integrate suppliers, employers, another storage warehouses and efficiently to products produced and distributed with the right quality, the right location and time to minimize costs and satisfy customer needs [8].

Another explanation by [9] suggested that the supply chain or can be translated to the supply chain is the set of relationships between companies or activities that carry out the distribution of the supply of goods or services from the place of origin to the place of the buyer or customers. Views horizontally, there are five major components or perpetrators in the supply chain, i.e. the supplier, manufacturer, wholesalers, retailer, customer. Vertically, there are five major components of the supply chain, i.e. the buyer, carrier, warehouses (storage), and seller. Supply chain evolves in three parts, namely [10]:

1.Upstream supply chain: this section includes a firsttier supplier of organizations and suppliers which have built a relationship.

2.The internal supply chain: this section includes all the processes used by organizations in changing the input that is sent by the supplier into the output, starting from the time the material entered in the company until the product is distributed in outside of the company.

3.Downstream supply chain: this section includes all the processes involved in the delivery of the product at the customer end.

\section{Partnership}

Partnership as a concept of cooperation has several criteria, i.e. done on more than one party, have the need itself, but have agreed to achieve the vision and goals to increase capacity. Scheme of partnership is a variation application within the framework of the partnership model. Patterns are examined in reference to the theory of pattern of small business partnerships, community empowerment and Corporate Social Responsibility. Other definitions mentioned that a partnership is defined as a set of invalid constructs associated with the processes that assist in guiding the flow of information between partners, manages the depth and breadth of interactions that are interwoven, and understand the necessary changes complex and dynamic between partners. A dimension commitment, coordination, dependency, and belief [11].

\section{Supply chain and partnership}

Agribusiness commodity on any subsystem there should be alignment that can improve the performance of the supply chain. These necessary social capital and partnership strategies are relation. Social capital in which there is trust, norms and networks will allow the occurrence of a relationship of cooperation. Partnership as one form of cooperation that intertwined among small businesses (including farmers) with medium or large businesses in the supply chain network by observing the principle of mutual need, strengthen each other, and mutual benefit. Social capital in which there is trust, norms and networks will allow the occurrence of a relationship of cooperation.

\section{METHOD}

This study will address the issue of increased and improved supply chain commodity Coffee Kintamani Bali conducted with qualitative research methods descriptive. The focus of the research that will be discussed is exploring various alternatives ways that can be applied as a whole and complete supply chain improvement. Data retrieval research done by the documentation steps, current or still in the planning stages in an effort to improve the supply chain Coffee Kintamani that are already proceeded. Analysis techniques to deduce the results of research is an interactive model of the [11], beginning from the stage of condensation of data, data collection, the presentation of the data and the last is the conclusion [12].

\section{RESUlTS AND DISCUSSION}

In general it is mentioned strategies that can be performed with, among others, through: (a) an increase in the value of coffee products Kintamani (differentiation of quality); (b) an increase in the value added functionally (downstream processing of raw beans); and (c) the increase in value through more efficient processes (productivity at the level of the better farmer) [3]. Efforts to realize the idea, there has been realized or still in the planning stages by the Government either area or Centre. These efforts include [3]:

1. The National Programme of Action people's Economic Synergies. People's Economic Action Synergy program is a program that was initiated by the Central Government by encouraging collaborative partnerships between state-owned enterprises, Ministries and private parties. This program has initiated various activities that seek to strengthen the commodity supply chain Coffee Kintamani Bali. The empowerment of coffee farmers through Kintamani post-harvest training as 
programs will provide technical assistance to farmer groups Hope Subak, Batur Village of Petung, middle, Kintamani integrated tourism resorts, which manages its between infrastructure development, increasing human resources, access to market to marketing the product. As said to be integrated because the two acres of land in addition to coffee also developed other agricultural products. In that location, you can also reap the coffee, see the creation process into powder and drink coffee as part of the agro-tourism [15].

3. The efforts to minimize the ways of marketing such as the existence of this village can be retrieved data as well as the latest innovations in the production process or the processing of coffee as one of the efforts to create a system of production and processing of the more modern [6]. [14]. (b) The Central Bank Indonesia through social

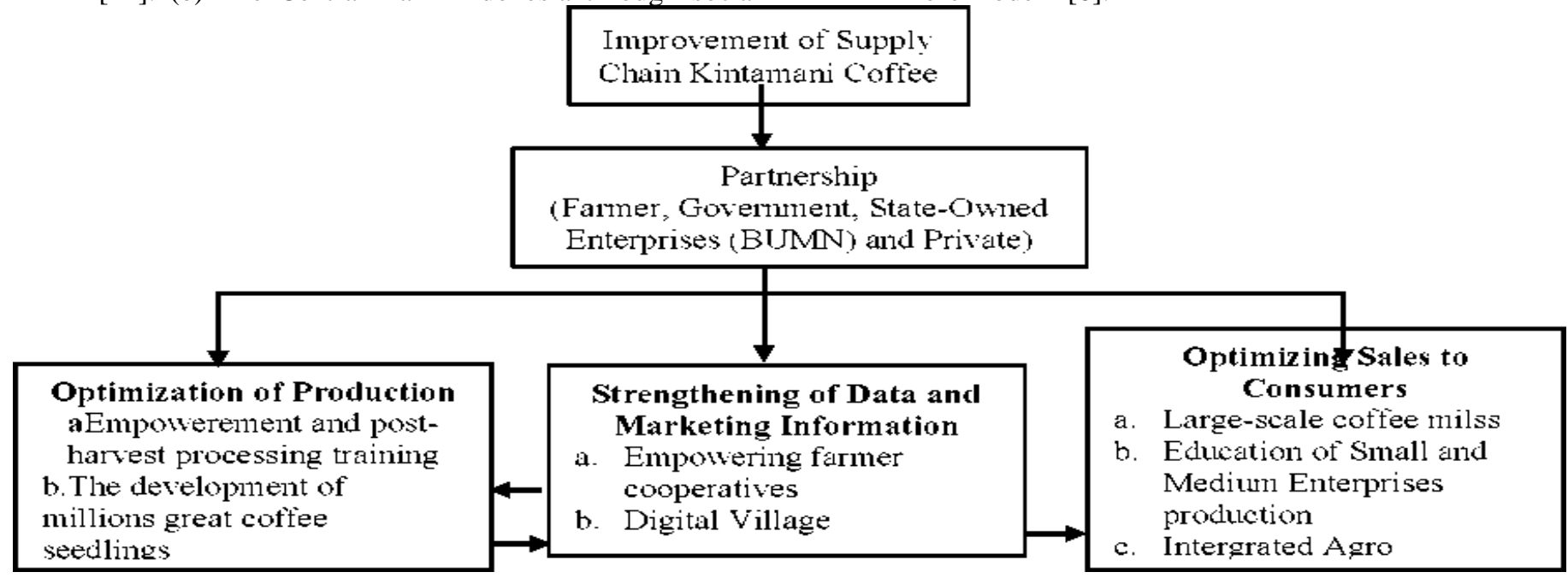

Figure 1 . The design of supply chain improvement model of kintamani coffee.

\section{REFERENCES}

\section{CONCLUSION}

The potential of Coffee commodity Kintamani Bangli Regency still do not give good well-being for the perpetrators, especially the farmers. The productivity of coffee production Kintamani is still not able to meet the large consumer market. Supply chain that is too long and not yet well-coordinated alleged to be one of the causes have not been optimal productivity efficient Kintamani coffee production.

Good Government Center or a regional partner with stateowned enterprises and the sector has been trying to trim the supply chains that are not yet effective and resulted in losses at the level of farmers. Through models of partnership initiated by the perpetrator of the coffee industry are expected to be able to produce a simple supply chain and able to provide optimal benefits for the farmers and the other market participants.
[1] Paat, W. 2018. Kopi Indonesi komoditas ekspor potensial. Retrieved from http://www.beritasatu.com. Accsessed 29 July 2018.

[2] Hendaryanti, D.D. \& Arianto, Y. 2017. Statistik perkebunan Indonesia 2015-2017. Jakarta: Sekretariat Direktorat Jendral Perkebunan Kementrian Pertanian.

[3] Neilson, J. 2015. Menuju rantai nilai yang lebih kompetitif dan dinamis untuk kopi Indonesia. Technical Report. Retrieved from http://www.researchgate.net. Accsessed 14 January 2018.

[4] Rahayu, E.M. 2016. Ini potensi 11 kopi khas daerah Indonesia. Swa. Retrieved from http://www.swa.co.id. Accsessed 5 January 2018

[5] Nursalikah, A. 2015. Kopi arabika kintamani jadi komoditas unggulan nasional. Republika. Retrieved from http://nasional.republika.co.id Accsessed 14 January 2018.

[6] Arnawa, K., Eka, N.M., Budiasa, M. \& Sukarna, G. 2010. Peningkatan kualitas dan kuantitas kopi arabika kintamani dalam upaya meningkatkan komoditas ekspor sektor perkebunan. Majalah Aplikasi Ipteks Ngayah 1(1): 63-70.

[7] Iskandar, E.D. 2016. Sinergi kementrian, BUMN, dan swasta mengharumkan kopi kintamani. SWA. Retrieved from http://www.swa.co.id. Accsessed 10 January 2018.

[8] Simichi-Levi, D. Philip, K. \& Simichi-Levi, E. 2003. Desinging and managing the supply chain: Concept, strategies and case studies. Singapore: Irwin McGraw-Hill. 
[13] Parananda, E. 2018. Tingkatkan produksi kopi, Bangli akan kembangkan pembibitan di Desa Catur. Balipost. Retrieved from http ://www. balipost. com. Accsessed 20 March 2018

[9] Assauri, S. 201). Manajemen produksi dan operasi. Jakarta: Lembaga Penerbit FEUI.

[10] Anatan, L. 2010. Pengaruh implementasi praktik-praktik manajemen rantai pasokan terhadap kinerja rantai pasok dan keunggulan kompetitif. Jurnal Karisma 4(2): 106-117.

[11] Mohr, J. \& Spekman, R. 1994. Characteristics of partnership success: Partnership attributes, communication behavior, and conflict resolution techniques. Strategic managementJournal 15(2): 135-152.

[12] Miles, M.B., Huberman, A.M. \& Saldana, J. 2014. Qualitative data analysis: A methods sourcebook. 3rd.

[14] Postbali.id. 2016. Bupati Bangli: Tingkatkan brand kopi kintamani. Retrieved from https://www.posbali.id/bupati-bangli-tingkatkan-brandkopi-kintamani/. Accsesed 2 July 2018.

[15] Prayogo, C. 2016. BI dorong peningkatan produksi kopi di Kintamani. Warta Ekonomi. Retrieved from http ://www. wartaekonomi .co.id. Accsessed 29 December 2017. 